\title{
RETURNS TO FIELD OF STUDY IN TRINIDAD AND TOBAGO: A GENDER PERSPECTIVE AND POLICY IMPLICATIONS
}

\author{
Roshnie A. Doon ${ }^{1 *}$ \\ ${ }^{1}$ Faculty of Social Sciences, The Sir Arthur Lewis Institute of Social and \\ Economic Studies (SALISES), \\ The University of the West Indies, Trinidad \\ ${ }^{1}$ Email: roshnie.doon@my.uwi.edu *(Corresponding author)
}

\begin{abstract}
This study seeks to examine the impact that the field of study of workers in Trinidad and Tobago is likely to have on their earning capacity. Using individual persons' data from the Continuous Sample Survey of the Population (CSSP), for the period 1991-2015, the returns of private and public sector workers were estimated by estimating a Mincerian Earnings function using the Quantile Regression technique. This study finds that men employed in low- and middleincome jobs for most fields (arts, humanities, science, engineering and architecture, social science, business, law, and mathematics and computer science and law enforcement) all suffered a wage decline in 2004-2015. This may be due to changes in the skill set where there was much growth in the industry demand for highlyskilled and unskilled men. This implies that middle income jobs which hire semiskilled men, may be possibly becoming more polarized during the 2009-2015 recession. Men employed in high income jobs, earn better wages in more fields, particularly STEM areas. The earnings of women employed in low, middle- and high-income jobs for most fields, especially in the areas of STEM all improved in 2004-2015. This is likely to be the result of the rising participation of women in STEM fields, and a greater integration of STEM competencies in STEM and NonSTEM occupations.
\end{abstract}

Keywords: Human capital, Mincerian Earnings Equation, Quantile Regression, STEM, Fourth Industrial Revolution.

https://doi.org/10.47412/ZKWQ5336

\section{Introduction}

One of the most significant choices students will make during their academic career, is likely to be the field in which they choose to become proficient. The field of specialty not only influences the students' employment prospects, but also the wage structure of workers in that given specialization. The decision to enter a specific field, may be influenced by not only the students' exposure to different subject areas, but also the funding of higher education through programmes such as the Government Assistance for Tuition Expenses (GATE), to access to higher modes of 
learning in a particular field of study in Trinidad and Tobago. Notwithstanding these factors, changes in Trinidad and Tobago's economic climate through periods of financial boom (19942008) and bust (2009-2015), when coupled with the advent of the digital age in the fourth industrial revolution, are all likely to influence the employment dynamics of various fields. Thus, it is necessary to examine how the wage returns of private and public sector workers trained in different fields of study evolved throughout the 1991-2015 timeframe.

In a time of economic uncertainty, such as Trinidad and Tobago's period of fiscal boom (19942008) and bust (2009-2015), choosing a field which offers a reasonable return may be crucial to maintaining the financial stability of new and potential workers in the future. Further to this, the returns of workers are also likely to be influenced by the introduction of educational policies concerning the funding of higher education, such as the GATE programme, and expansion of postsecondary institutions such as the National Institute of Higher Education, Research, Science and Technology (NIHERST), and the Metal Industries Company Institute of Technology (MIC-IT) and the National Energy Skills Centre (NESC). A study of this nature may assist current workers and graduates who are now entering the workforce, to identify based on their field of study, where labour market shortages may exist and what may possibly cause their returns to vary over time.

By undertaking this study, it contributes to the empirical literature of educational economics in six ways. First, to the best knowledge of the author, this is the first study to investigate the returns to field of study for Trinidad and Tobago. Second, this study illustrates how the returns evolve across the complete wage distribution and across two cohorts, i.e., 1991-2003 and 2004-2015, while allowing for the presence of endogeneity. Third, this is the first study to examine the presence of gender disparity of returns by field of study for Trinidad and Tobago. Fourth, this is also the first study to examine the returns to schooling for Trinidad and Tobago in general and by gender, for the past 24 years, i.e., 1991-2015. Fifth, this is the first study to quantitatively highlight the presence of Skilled Based Technical Change (SBTC) and Job Polarization in Trinidad and Tobago. Sixth and finally, this study adds to the empirical findings of the only other developing country study done by Pinitjisamut (2012), which examined the returns to field of study for collegeeducated workers in Thailand. This manuscript is structured as follows, a brief review of the literature is provided, which is followed by a discussion of the data, and econometric methodology; an anlysis of the empirical findings, and a short conclusion.

\section{Literature Review}

Traditionally, while the body of literature on educational economics has focused on examining the returns to schooling, and the persistence of educational misalignment, there is limited studies done on the area which examines the returns to the fields of study [16]. This is supported by Altonji (1993, p. 49), who indicates that "most of the literature on the returns to education ignores the large differences in earnings by field and the fact that choice of majors often changes during college." One possible reason for this is likely to be related to the lack of available data, and datasets which collect information on a broad range of fields of study, which allow one to examine both the returns, and the endogeneity of educational fields [7, 8]. 
A brief examination of studies, shows that the research done focuses generally on the returns associated workers/graduates with university/college education at both the undergraduate and graduate level, as well as degree majors at the undergraduate level, reveals that in countries such as the United States (US), Canada, South East Asia and Europe, workers who majored in Science, Technology, Engineering and Mathematics (STEM) and Business fields, were more likely to be amongst the highest income earners, than workers whose majors were in fields such as Humanities, Education and Liberal Arts [3, 6]. According to Arcidiacono (2004), such a divergence in returns, is likely to be the result of ability sorting in the workplace. Employers, may possibly sort workers based on their preference for a particular college major based on the characteristics of the job and the firm, as well as specific abilities and skills which they are likely to be considered to be more lucrative in building and sustaining future earnings.

\section{Data}

The data used in this study came from the Continuous Sample Survey of Population (CSSP) undertaken by Trinidad and Tobago's Central Statistical Office (CSO). Using selected labour force statistics from the CSSP for the period 1991-2015, two samples were chosen to examine the impact that the workers' field of study may have on their earnings capability. The these two samples comprise of workers ages 15-65, who are engaged in permanent employment, i.e. working more than 33 hours per week, within both the private and public sector, but are restricted by gender. In order to take into account the changes in the business cycle resulting from the fiscal boom (19942008) and bust (2009-2015), educational policies inclusive of the GATE programme, the returns were estimated over two cohorts, i.e., 1991-2003 and 2004-2015. A wide array of control variables which reflect the characteristic features of the worker include their hourly work rate, highest field of study, main field of study, level of study, over and under education, years of schooling, mother and fathers' education, working experience, gender, marital status, ethnicity, occupation, industry, county divisions and level of skill.

\section{Econometric Methodology}

\subsection{The Mincerian Approach [12]}

Drawn from the ideologies of Becker (1975) concerning specific training within different fields of study, there are two specifications of specific training. The first refers to any education received, such as training provided internally, which may enhance the productivity of the business offering it to the workers. The second type, known as complete training, "has no effect on the productivity of trainees that would be useful in other firms," (Becker 1975, p. 26). The provision of specific training in a particular field is either borne by either the worker, or their employer. As Becker (1975, p. 28) explains that if the employer covers the cost of training workers then they, "would collect the returns from such training in the form of larger profits resulting from higher productivity, and training would be provided whenever the return was at least as large as the cost.” However, such provision is not done without risk, as the employer stands to experience a loss should the specifically trained worker decide to end his job contract prematurely. Bearing in mind the views of Becker (1975), this study will make use of a pooled Ordinary Least Squares version of the Mincerian [12] wage equation to estimate the returns to fields of study as specified as;

$$
\begin{aligned}
& \ln w_{i}=\beta_{0}+\beta_{1} F_{i}+\beta_{2} X_{i}+e_{i} \\
& \ln w_{i}=\beta_{0}+\beta_{1} S_{i}+\beta_{2} X_{i}+e_{i}
\end{aligned}
$$


where for the $i^{\text {th }}$ worker, $\ln w$ is the natural logarithm of the real hourly wage [\%], $F_{i}$ is a set of dummy variables reflecting the workers' specific field of study, $S_{i}$ is the workers years of schooling, $\boldsymbol{X}_{i}$ is the vector of control variables mentioned earlier., the variables which reflect the and $e_{i}$ the error term.

\subsection{The Quantile Regression (QR) Approach}

The Mincerian equation specified by equation (1) and (2) above, is also estimated using the Quantile Regression (QR) technique [9,11]. This approach is used because it allows for the characterization of the entire wage distribution by stating specific cut-off points [9, 11]. For purposes of this study, the wage distribution is separated into five segments to reflect the $10^{\text {th }}, 25^{\text {th }}$, $50^{\text {th }}, 75^{\text {th }}$, and $95^{\text {th }}$ quantiles. Highlighting that these specific points are crucial, as the impact that a workers' field of study is likely to have on their wage returns, may vary across the entire wage distribution. Thus, the field of study may possibly influence the returns of low, middle and high income workers differently, depending on their individual level of skill, and the years of schooling spent in a particular field. Given the above, the quantiles regression is specified by Koenker and Hallock (2001) as;

$$
\ln w_{i}=X_{i} \beta_{\tau}+e_{\tau i}, \tau\left(\ln w_{i} \mid X_{i}\right)=X_{i} \beta_{\tau}
$$

where for the ith worker, $\ln w_{i}$ is the natural logarithm of the real hourly wage rate [\%], $\boldsymbol{X}_{\boldsymbol{i}}$ the vector of the set of independent variables (control variables), $e$ is the error term, $\beta_{\tau}$ the unknown vector of parameters (constant), $\tau$ the sample quantile, and $\tau\left(\ln w_{i} \mid \boldsymbol{X}_{\boldsymbol{i}}\right)$ the conditional quantile $(\tau)$ of the ith workers' hourly wage rate $\left(\ln w_{i}\right)$ given the vectors of independent variables $\left(\boldsymbol{X}_{\boldsymbol{i}}\right)$.

\section{Empirical Results and Analysis}

\subsection{Returns to Schooling by Gender}

To set the context of the discussion, first the returns to schooling of both men and women was examined and the results presented by Table 1 in the appendix. The z-test shows that there was no difference in the returns to schooling for both men and women. The returns to schooling of women was found to be higher than that of men for both the 1991-2003 and 2004-2015 cohorts. The average returns of both men (from 9.6\% to 7.7\%) and women (from 15.5\% to $11.2 \%$ ) declined across 1991-2003 to 2004-2015. This is likely to reflect the changes in the business cycle resulting from the 2009-2015 economic recession. In the context of the Caribbean, Coppin (1997) and Olsen and Coppin (2001) argue that this is likely to be a reflection of improved economic environment during the 1994-2008 boom, changing social norms with regards to women's involvement in the workplace, and the evolution of post-colonial education policies, all of which may have placed more value on the education of women and girls. Thus easing female access to primary and secondary schooling.

\subsection{Returns to Field of Study by Gender}

The average returns of men, regardless of field of study, was higher than that of women in both 1991-2003 and 2004-2015 as shown in Tables 2 and 3 below in the appendix. The z-tests indicates that there is no difference in the returns to field of study for both men and women. The average returns of men, for all fields except those employed in transport and services declined in 20042015, while that of women, although negative, improved for all fields except for those employed in the area of law enforcement in 2004-2015. For much of 1991-2003 and 2004-2015 periods, the 
impact that the field of study has across the wage distribution, is larger for men between q95-q10, and for women between q75-q25.

\subsubsection{The Male Returns to Field of Study}

An analysis of the quantile regression estimates in Table 2 below, reveals that the returns of men in the majority of fields (arts, humanities and education, engineering and architecture, transport and services) improved across the wage distribution, in the 1991-2003 and 2004-2015. For men in the fields of social science and business, their returns declined from q10 - q25 in 1991-2003, but increased across the wage distribution in 2004-2015. For the remaining fields (science, law, mathematics and computer science, and law enforcement), their returns eroded, either throughout the wage distribution or at the lower quantiles, i.e., either from q10-q25 or q10-q50.

The wage pattern emerging from Table 2, when summarized by Table 4 in the appendix, reveals several important discoveries concerning the returns of men. First, men in low, and middle income jobs in the majority of fields (such as arts, humanities, science, engineering and architecture, social science, business, law, and mathematics and computer science and law enforcement) all suffer a wage decline in 2004-2015. This outcome maybe the result of both the skill composition of men, where there is much growth of semi-skilled (from $75.1 \%$ to $75.87 \%$ ), and unskilled men (from $16.68 \%$ to $15.99 \%$ in $2004-2015$ ), compared to the small segment of highly skilled men (from $8.22 \%$ to $8.14 \%$ ) during $1991-2003$ to $2004-2015$ based on the sample used for this study.

An examination of industry employment by skill, reveals that most industries tend to demand more highly skilled and unskilled men, than that of semi-skilled men. This disconnect between the skills supplied to the labour market, and what is demanded by industrial enterprises, may possibly indicate that the middle income jobs hiring semi-skilled men are becoming more polarized during the 2009-2015 recession. This, according to Coelli and Borland (2016), is not unheard of as their study which looks at the polarization and wage inequality in Australia, revealed that the phenomenon tends to affect men more than women.

Second, in 2004-2015, men employed in a high income jobs faired better in more fields, primarily STEM related (science, engineering and architecture, medicine and veterinary science, social science, law, and law enforcement), than those in the fields of arts, humanities and education, business, mathematics and computer science, transport and services. It is likely that the greater integration of men in STEM fields across industries, may possibly lead to higher returns during the recession because the demand for higher achieving men in STEM fields is growing amongst industries.

\subsubsection{The Female Returns to Field of Study}

In comparison to that of men above, the returns of women shown by Table 3 in the appendix, for the majority of fields, improved across the wage distribution, with most of the wage erosion taking place in 1991-2003, at the mid-upper quantile, i.e., q50-q75 position on the wage distribution. In 2004-2015, the returns of women in the majority of the fields eroded at the lower-mid portion of the wage distribution, i.e., q10-q50, before improving, while those in fields such as science, and law enforcement deteriorated throughout the wage distribution. In general, regardless of the field of study, the returns of men generally worsened in 2004-2015, when compared to that of women which improved for the same time period. 
Upon careful reflection of Table 3, when summarized by Table 4 in the appendix shows that, the returns of women employed in low, middle and high income jobs for the majority of fields, but primarily STEM fields, all improved in 2004-2015. The fields in which women, predominantly experienced a drop in earnings are law and law enforcement if employed in middle income jobs, and arts, humanities and education, mathematics and computer science, and law enforcement if employed in high income jobs. The improvement in the returns of women in STEM fields may have been influenced by changes in industry demand and supply, as well as employer preferences. First, the expansion of programmes such as GATE may have changed the gender dynamics of STEM fields. Thus enabling more women to enter into STEM fields. This growth may have brought closer the gender gap in STEM fields, as the composition of highly skilled women (engineering and architecture, and mathematics and computer science), semi-skilled women (all STEM fields), and unskilled women all grew in 2004-2015. The majority of these women, appear to be integrated into a wide variety of industries in 2004-2015.

Second, the wide integration of women in STEM across a wide array of industries and the rising returns across wage distribution, may indicate that employers are likely to be placing greater emphasis on the competencies associated with STEM fields. In that employers maybe taking a more interdisciplinary approach to profit generation by hiring more women in STEM, as they are likely to possess a diverse range of skills and abilities to meet the needs of both STEM and NonSTEM industry type jobs.

Third, women in STEM fields, according to Beede et al., (2011) although earning more than women in Non-STEM fields, are more likely to work in Non-STEM related occupations. This leakage in the "STEM pipeline," occurs because of factors such as limited job creation in STEM fields, gender stereotyping, and the inflexibility of STEM jobs. The difference is especially prominent amongst high achieving American men and women [14]. Apart from the factors listed above, the growth in over educated women, i.e. highly educated women, due to the ease of access to STEM programmes at the university level through the GATE programme (medicine and veterinary science, engineering and architecture) and under educated women (science, medicine and veterinary science, and mathematics and computer science) in these respective fields in Trinidad and Tobago, may also encourage women in STEM to enter Non-STEM occupations where their earnings are likely to be higher. Fourth, the returns of women in Non-STEM fields (social science, business, and transport and services), also improved in 2004-2015. In spite of this, the majority of industries did not absorb more women in the business, social science and transport and services, in 2004-2015. It is possible, that this may have occurred because of industry saturation and limited job opportunities.

\section{Conclusion}

Creating and sustaining, the innovativeness and competitiveness of any economy is often associated with the quality of the human capital asset base of that country. Government bodies and employers alike, may encourage students, potential and current workers to enter fields which can provide greater financial stability, while addressing these concerns. To do this, many postsecondary educational opportunities are provided, through the expansion and restructuring of higher educational institutions and higher educational funding programmes such as the Dollar-for- 
Dollar and GATE. The expansion of such education and funding opportunities, is likely to have eased the access of both students and workers to enter into a range of different fields of studies, ranging from purely academic to technical/vocational areas. However, in the midst of the 20092015 recession, the advent of the fourth industrial revolution, and the realization of the digital age, the employment dynamics of the various fields are likely to change. Thus, it is crucial to examine how the returns of workers in different fields evolved during 1991-2003 and 2004-2015.

In doing so, this study contributes to the literature on the returns to field of study in five ways, first to the best knowledge of the author, this is the first study to examine the returns to field of study for Trinidad and Tobago. Second, this is the first study to highlight the intensification of SBTC, i.e., the shift in the production technology that favors more educated and experienced labour, over unskilled labor, and Job Polarization, i.e., the erosion of middle class workers in Trinidad and Tobago. Third, this is also the first study to examine the gender disparity of returns by field of study in Trinidad and Tobago. Fourth, this is also the first study to examine the evolution of the returns to schooling across a period of 24 years for Trinidad and Tobago. Fifth and finally, this study illustrates how these returns progress across the wage distribution, and over the time frame.

By undertaking such estimation and subsequent analysis, this study has made several findings. First, both the average returns to schooling and the returns to field of study, for a majority of fields have worsened in 2004-2015. Second, workers employed in low and high income jobs for the majority of fields, benefitted from higher returns in 2004-2015, when compared to the fields of business, mathematics and computer science. Third, private sector workers and those employed in middle income jobs, in the majority of fields suffered a decline in returns in 2004-2015. Fourth, both the average returns to schooling and the returns to field of study, for a majority of fields were higher for women than men. Fifth, regardless of field of study, the returns of men worsened in 2004-2015, when compared to that of women which improved. Sixth, the men in low, and middle income jobs in the majority of fields all suffered a wage decline in 2004-2015. Seventh, men employed in high income jobs, faired better in more fields, particularly in STEM areas. Eighth, the returns of women employed in low, middle and high income jobs for the majority of fields, especially STEM fields, all improved in 2004-2015.

Bearing in mind the outcome of this study, there are several policy implications which may arise. In that the short lived resilience of small and middle income jobs, as well as the presence of SBTC and employment polarization, are likely to contribute to the displacement of middle income workers, as well as the growth of unskilled workers. Taking into consideration these findings and implications, it is possible to improve the returns of the various fields in three ways. First, integrate more entrepreneurship type courses within all programmes at the university level. Second, provide STEM training for workers trained in Non-STEM fields. Third, bearing in mind the increasing digitalization of the labour market and the polarization of middle income jobs, additional training, and retraining should be provided to workers who are likely to be displaced. 


\section{References}

[1] J. Altonji. 1993. The Demand for and Returns to Education When Education outcomes are Uncertain. Journal of Labor Economics, 11(1), 48-83. Retrieved from http://www.jstor.org/stable/2535184.

[2] P. Arcidiacono. 2004. Ability Sorting and the Returns to College Major. Journal of Econometrics, 121, 343-375. doi:10.1016/j.jeconom.2003.10.010.

[3] M. Beblavy, S. Lehouelleur, I. Maselli. 2015. How the Returns from Tertiary Education differ by Field of Study. Implications for Policy makers and students. Brussels: Belgium: Centre for European Policy Studies.

[4] G. Becker. 1975. Human Capital: A Theoretical and Empirical Analysis, with Special Reference to Education. Cambridge, Massachusetts. National Bureau of Economic Research (NBER).

[5] A. Coppin, A. 1997. Women's Earnings in Trinidad and Tobago: An Analysis by Household Status and Ethnicity. Social and Economic Studies, 46(4), 61-82. Retrieved from https://www.jstor.org/stable/27866152.

[6] J. Fan, J., C. Zhang. 2015. A Study of the Rate of Return to Higher Engineering Education in China. International Journal of Educational Development, 42, 106-114. doi.org/10.1016/j.ijedudev.2015.04.010.

[7] D. Glocker, J. Stork. 2014. Risks and Returns to Educational Fields-A financial Asset Approach to Vocational and Academic Education. Economics of Education Review 42, 109129. doi.org/10.1016/j.econedurev.2014.06.004.

[8] E. Kelly, P. O’Connell, E. Smyth. 2010. The Economic Returns to Field of Study and Competencies among Higher education Graduates in Ireland. Economics of Education Review, 29, 650-657. doi:10.1016/j.econedurev.2009.11.001.

[9] R. Koenker, G. Bassett. 1978. Regression Quantiles. Econometrica, 46 (1), 33. $10.2307 / 1913643$.

[10] R. Koenker, K. Hallock. 2001. Quantile Regression. The Journal of Economic Perspectives, 15 (4), 143-156. doi: 10.1257/jep.15.4.143.

[11] R. Koenker. 2004. Quantile regression for Longitudinal data. Journal of Multivariate Analysis, 91 (1), 74-89. doi:10.1016/j.jmva.2004.05.006.

[12] J. Mincer. 1958. "Investment in Human Capital and Personal Income Distribution." Journal of Political Economy, 66(4):281-302. Accessed October 18, 2018. https://www.jstor.org/stable/1827422.

[13] R. Olsen, A. Coppin. 2001. The impact of Privatization on Relative Earnings in the Caribbean Region: Evidence from the Economy of Trinidad and Tobago. The Journal of Developing Areas, 40(2), 51-74.

[14] N. Otlisky. 2014. How do Academic Achievement and Gender Affect the Earnings of STEM Majors? A Propensity Score Matching Approach. Research in Higher Education, 55, 245-271. doi: 10.1007/s11162-013-9310-y.

[15] M. Pinitjitsamut. 2012. An estimation of Lifetime earnings and Return on Undergraduate education investment for different fields: A case of Thailand. International Journal of Education Economics and Development, 3,149-163. doi: 10.1504/IJEED.2012.047101. 


\section{Appendix}

\begin{tabular}{|c|c|c|c|c|c|c|c|c|c|}
\hline \multirow{2}{*}{$\begin{array}{l}\text { Year } \\
\text { Cohort }\end{array}$} & \multicolumn{9}{|c|}{ Private \& Public Sector Workers } \\
\hline & OLS & q10 & q25 & q50 & q75 & q95 & $\begin{array}{l}\Delta q 95- \\
q 10\end{array}$ & $\begin{array}{l}\Delta q 75- \\
q 25\end{array}$ & z-test \\
\hline \multicolumn{10}{|c|}{ Panel A: Male } \\
\hline \multirow[t]{2}{*}{$1991-2003$} & $\begin{array}{l}0.096 \\
* * *\end{array}$ & $\begin{array}{l}0.101 \\
* * *\end{array}$ & $\begin{array}{l}0.100 \\
* * *\end{array}$ & $\begin{array}{l}0.091 \\
* * *\end{array}$ & $\begin{array}{l}0.089 \\
* * *\end{array}$ & $\begin{array}{l}0.088 \\
* * *\end{array}$ & -0.013 & -0.011 & 11.426 \\
\hline & $(0.003)$ & $(0.006)$ & $(0.004)$ & $(0.003)$ & $(0.004)$ & $(0.004)$ & & & \\
\hline \multirow[t]{2}{*}{ 2004-2015 } & $\begin{array}{l}0.077 \\
* * *\end{array}$ & $\begin{array}{l}0.079 \\
* * *\end{array}$ & $\begin{array}{l}0.081 \\
* * *\end{array}$ & $\begin{array}{l}0.078 \\
* * *\end{array}$ & $\begin{array}{l}0.075 \\
* * *\end{array}$ & $\begin{array}{l}0.076 \\
* * *\end{array}$ & -0.003 & -0.006 & 11.856 \\
\hline & $(0.003)$ & $(0.006)$ & $(0.042)$ & $(0.003)$ & $(0.003)$ & $(0.006)$ & & & \\
\hline \multicolumn{10}{|c|}{ Panel B: Female } \\
\hline \multirow[t]{2}{*}{$1991-2003$} & $\begin{array}{l}0.155 \\
* * *\end{array}$ & $\begin{array}{l}0.212 \\
* * *\end{array}$ & $\begin{array}{l}0.188 \\
* * *\end{array}$ & $\begin{array}{l}0.151 \\
* * *\end{array}$ & $\begin{array}{l}0.124 \\
* * *\end{array}$ & $\begin{array}{l}0.103 \\
* * *\end{array}$ & -0.109 & -0.064 & 12.190 \\
\hline & $(0.005)$ & $(0.009)$ & $(0.006)$ & $(0.006)$ & $(0.007)$ & $(0.006)$ & & & \\
\hline \multirow[t]{2}{*}{ 2004-2015 } & $\begin{array}{l}0.112 \\
* * *\end{array}$ & $\begin{array}{l}0.137 \\
* * *\end{array}$ & $\begin{array}{l}0.126 \\
* * *\end{array}$ & $\begin{array}{l}0.116 \\
* * *\end{array}$ & $\begin{array}{l}0.098 \\
* * *\end{array}$ & $\begin{array}{l}0.078 \\
* * *\end{array}$ & -0.059 & -0.028 & 12.724 \\
\hline & $(0.004)$ & $(0.007)$ & $(0.006)$ & $(0.005)$ & $(0.005)$ & $(0.006)$ & & & \\
\hline
\end{tabular}

Note: The coefficient values are statistically significant at all conventional levels of alpha $(* * * 0.01, * * 0.05$, and *0.10). Robust standard errors are shown in parenthesis. The dependent variable is the logarithmic of the real hourly wage rate.

Source: Own Calculations.

Table 2. Male Returns to Field of Study (\%)

\begin{tabular}{|c|c|c|c|c|c|c|c|c|c|}
\hline \multirow{2}{*}{$\begin{array}{l}\text { Fields of } \\
\text { Study } \\
\text { Panel A: 1991-2003 }\end{array}$} & \multicolumn{9}{|c|}{ Male Private \& Public Sector Workers } \\
\hline & OLS & q10 & q25 & q50 & q75 & q95 & $\begin{array}{r}\Delta \mathrm{q} 95- \\
\mathrm{q} 10\end{array}$ & $\begin{array}{r}\Delta q 75- \\
\text { q25 }\end{array}$ & z-test \\
\hline $\begin{array}{l}\text { Arts, Humanities \& } \\
\text { Education }\end{array}$ & -0.006 & $\begin{array}{l}-0.038 \\
*\end{array}$ & -0.001 & 0.014 & -0.003 & 0.012 & 0.050 & -0.002 & 0.049 \\
\hline & $(0.013)$ & $(0.019)$ & $(0.018)$ & $(0.013)$ & $(0.016)$ & $(0.024)$ & & & \\
\hline Science & $\begin{array}{l}0.114 \\
* * * \\
(0.015)\end{array}$ & $\begin{array}{l}0.150 \\
* * * \\
(0.024)\end{array}$ & $\begin{array}{l}0.101 \\
* * * \\
(0.020)\end{array}$ & $\begin{array}{l}0.099 \\
* * * \\
(0.016)\end{array}$ & $\begin{array}{l}0.079 \\
* * * \\
(0.018)\end{array}$ & $\begin{array}{l}0.067 \\
* \\
(0.041)\end{array}$ & -0.083 & -0.022 & 0.025 \\
\hline Engineering \& & 0.132 & 0.051 & 0.081 & 0.140 & 0.177 & 0.201 & 0.150 & 0.096 & 0.067 \\
\hline Architecture & $\begin{array}{l}* * * \\
(0.013)\end{array}$ & $\begin{array}{l}* \\
(0.023)\end{array}$ & $\begin{array}{l}* * * \\
(0.017)\end{array}$ & $\begin{array}{l}* * * \\
(0.016)\end{array}$ & $\begin{array}{l}* * * \\
(0.016)\end{array}$ & $\begin{array}{l}* * * \\
(0.029)\end{array}$ & & & \\
\hline Medicine \& & 0.219 & 0.107 & 0.171 & 0.222 & 0.266 & 0.206 & 0.099 & 0.095 & 0.130 \\
\hline Veterinary Science & $\begin{array}{l}* * * \\
(0.022)\end{array}$ & $\begin{array}{l}* \\
(0.036)\end{array}$ & $\begin{array}{l}* * * \\
(0.030)\end{array}$ & $\begin{array}{l}* * * \\
(0.038)\end{array}$ & $\begin{array}{l}* * * \\
(0.025)\end{array}$ & $\begin{array}{l}* * * \\
(0.052)\end{array}$ & & & \\
\hline Social Science & $\begin{array}{l}0.158 \\
* * * \\
(0.024)\end{array}$ & $\begin{array}{l}0.107 \\
* \\
(0.039)\end{array}$ & $\begin{array}{l}0.104 \\
* * * \\
(0.029)\end{array}$ & $\begin{array}{l}0.162 \\
* * * \\
(0.029)\end{array}$ & $\begin{array}{l}0.183 \\
* * * \\
(0.030)\end{array}$ & $\begin{array}{l}0.148 \\
* * * \\
(0.057)\end{array}$ & 0.041 & 0.079 & 0.012 \\
\hline Business & $\begin{array}{l}0.240 \\
* * * \\
(0.011)\end{array}$ & $\begin{array}{l}0.219 \\
* * * \\
(0.017)\end{array}$ & $\begin{array}{l}0.215 \\
* * * \\
(0.013)\end{array}$ & $\begin{array}{l}0.245 \\
* * * \\
(0.013)\end{array}$ & $\begin{array}{l}0.255 \\
* * * \\
(0.014)\end{array}$ & $\begin{array}{l}0.243 \\
* * * \\
(0.022)\end{array}$ & 0.024 & 0.04 & 0.094 \\
\hline Law & $\begin{array}{l}0.391 \\
* * * \\
(0.048)\end{array}$ & $\begin{array}{l}0.271 \\
* * * \\
(0.048)\end{array}$ & $\begin{array}{l}0.408 \\
* * * \\
(0.042)\end{array}$ & $\begin{array}{l}0.398 \\
* * * \\
(0.052)\end{array}$ & $\begin{array}{l}0.395 \\
* * * \\
(0.045)\end{array}$ & $\begin{array}{l}0.310 \\
* * * \\
(0.036)\end{array}$ & 0.039 & -0.013 & 0.003 \\
\hline $\begin{array}{l}\text { Mathematics \& } \\
\text { Computer Science }\end{array}$ & $\begin{array}{l}0.250 \\
* * * \\
(0.016)\end{array}$ & $\begin{array}{l}0.251 \\
* * * \\
(0.032)\end{array}$ & $\begin{array}{l}0.248 \\
* * * \\
(0.020)\end{array}$ & $\begin{array}{l}0.257 \\
* * * \\
(0.019)\end{array}$ & $\begin{array}{l}0.246 \\
* * * \\
(0.019)\end{array}$ & $\begin{array}{l}0.198 \\
* * * \\
(0.031)\end{array}$ & -0.053 & -0.002 & 0.020 \\
\hline
\end{tabular}




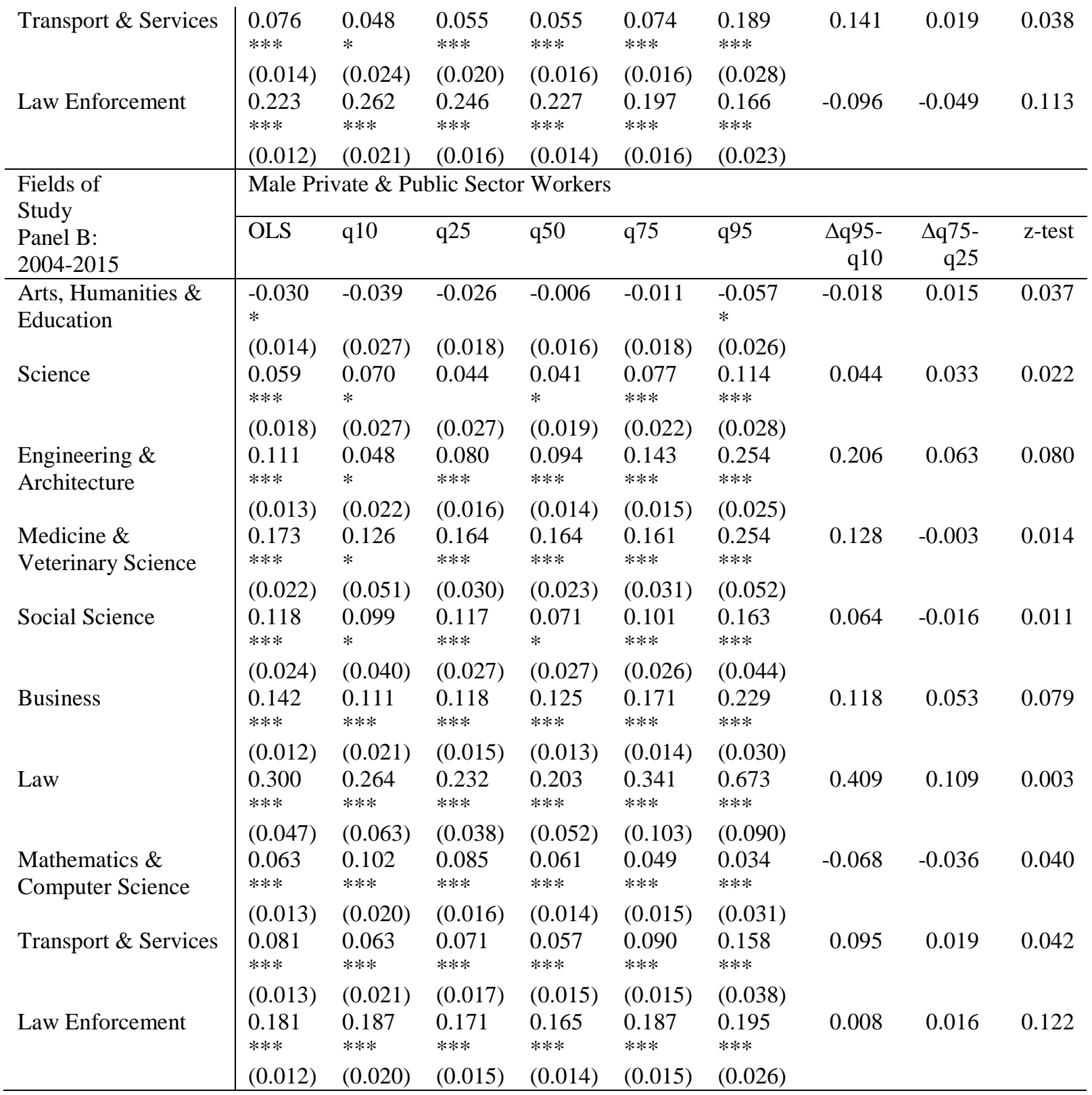

Note: The coefficient values are statistically significant at all conventional levels of alpha $\left({ }^{* * *} 0.01,{ }^{* *} 0.05\right.$, and *0.10). Robust standard errors are shown in parenthesis. The dependent variable is the logarithmic of the real hourly wage rate.

Source: Own Calculations.

Table 3. Female Returns to Field of Study (\%)

\begin{tabular}{|c|c|c|c|c|c|c|c|c|c|}
\hline \multirow{2}{*}{$\begin{array}{l}\text { Fields of } \\
\text { Study } \\
\text { Panel A: } \\
\text { 1991-2003 }\end{array}$} & \multicolumn{9}{|c|}{ Female Private \& Public Sector Workers } \\
\hline & OLS & q10 & q25 & q50 & q75 & q95 & $\begin{array}{l}\Delta \mathrm{q} 95- \\
\text { q10 }\end{array}$ & $\begin{array}{l}\Delta \text { q75- } \\
\text { q25 }\end{array}$ & z-test \\
\hline Arts, & -0.160 & -0.184 & -0.140 & -0.132 & -0.153 & -0.090 & 0.094 & 0.293 & 0.138 \\
\hline Humanities & $* * *$ & $* * *$ & *** & *** & $* * *$ & * & & & \\
\hline \& Education & $(0.024)$ & $(0.042)$ & $(0.030)$ & $(0.029)$ & $(0.027)$ & $(0.046)$ & & & \\
\hline
\end{tabular}




\begin{tabular}{|c|c|c|c|c|c|c|c|c|c|}
\hline Science & $\begin{array}{r}-0.161 \\
* * * \\
(0.030)\end{array}$ & $\begin{array}{r}-0.094 \\
* \\
(0.051)\end{array}$ & $\begin{array}{r}-0.160 \\
* * * \\
(0.034)\end{array}$ & $\begin{array}{r}-0.159 \\
* * * \\
(0.034)\end{array}$ & $\begin{array}{r}-0.170 \\
* * * \\
(0.037)\end{array}$ & -0.085 & 0.009 & 0.33 & 0.022 \\
\hline Engineering & -0.115 & -0.205 & -0.163 & -0.042 & -0.088 & -0.023 & 0.182 & 0.251 & 0.009 \\
\hline & $* * *$ & $* * *$ & $* * *$ & & $*$ & & & & \\
\hline Architecture & (0.039) & $(0.059)$ & (0.059) & $(0.041)$ & $(0.046)$ & $(0.084)$ & & & \\
\hline Medicine \& & -0.086 & -0.068 & -0.104 & -0.104 & -0.118 & -0.081 & -0.013 & 0.222 & 0.081 \\
\hline Veterinary & $* * *$ & & $* * *$ & $* * *$ & $* * *$ & $*$ & & & \\
\hline Science & $(0.024)$ & $(0.044)$ & $(0.031)$ & $(0.029)$ & $(0.027)$ & $(0.047)$ & & & \\
\hline Social & -0.093 & -0.099 & -0.075 & -0.093 & -0.153 & -0.092 & 0.007 & 0.228 & 0.021 \\
\hline \multirow{2}{*}{ Science } & $* * *$ & & * & $* * *$ & $* * *$ & & & & \\
\hline & $(0.029)$ & $(0.047)$ & $(0.036)$ & $(0.032)$ & $(0.034)$ & $(0.075)$ & & & \\
\hline \multirow[t]{2}{*}{ Business } & -0.060 & -0.064 & -0.048 & -0.061 & -0.076 & -0.041 & 0.023 & 0.124 & 0.403 \\
\hline & $(0.022)$ & $(0.038)$ & $(0.027)$ & $(0.027)$ & $(0.026)$ & $(0.043)$ & & & \\
\hline \multirow[t]{2}{*}{ Law } & 0.002 & $\begin{array}{r}-0.180 \\
*\end{array}$ & -0.051 & 0.055 & $\begin{array}{r}0.135 \\
*\end{array}$ & $\begin{array}{r}0.169 \\
*\end{array}$ & 0.349 & -0.084 & 0.006 \\
\hline & $(0.047)$ & $(0.070)$ & $(0.075)$ & $(0.052)$ & (0.059) & $(0.076)$ & & & \\
\hline Mathematics & -0.076 & -0.058 & -0.080 & -0.080 & -0.103 & -0.057 & 0.001 & 0.183 & 0.064 \\
\hline \& Computer & $* * *$ & & $* * *$ & $* * *$ & $* * *$ & & & & \\
\hline Science & $(0.024)$ & $(0.042)$ & $(0.030)$ & $(0.029)$ & $(0.029)$ & $(0.046)$ & & & \\
\hline Transport \& & -0.231 & -0.223 & -0.222 & -0.235 & -0.243 & -0.195 & 0.028 & 0.465 & 0.211 \\
\hline \multirow[t]{2}{*}{ Services } & $* * *$ & $* * *$ & $* * *$ & $* * *$ & $* * *$ & $* * *$ & & & \\
\hline & $(0.022)$ & $(0.034)$ & $(0.028)$ & $(0.027)$ & $(0.026)$ & $(0.043)$ & & & \\
\hline \multirow{3}{*}{$\begin{array}{l}\text { Law } \\
\text { Enforcement }\end{array}$} & 0.091 & 0.060 & 0.103 & 0.117 & 0.088 & 0.106 & 0.046 & -0.191 & 0.022 \\
\hline & *** & & $* * *$ & $* * *$ & $*$ & & & & \\
\hline & $(0.030)$ & $(0.056)$ & $(0.037)$ & $(0.036)$ & $(0.035)$ & $(0.069)$ & & & \\
\hline \multirow{2}{*}{$\begin{array}{l}\text { Fields of } \\
\text { Study } \\
\text { Panel B: } \\
\text { 2004-2015 }\end{array}$} & \multicolumn{9}{|c|}{ Female Private \& Public Sector Workers } \\
\hline & OLS & $\mathrm{q} 10$ & $\mathrm{q} 25$ & q50 & q75 & q95 & $\begin{array}{l}\mathrm{q} 95- \\
\mathrm{q} 10\end{array}$ & $\begin{array}{l}\Delta q 75- \\
q 25\end{array}$ & z-test \\
\hline $\begin{array}{l}\text { Arts, } \\
\text { Humanities }\end{array}$ & $\begin{array}{r}-0.112 \\
* * *\end{array}$ & $\begin{array}{r}-0.138 \\
* * *\end{array}$ & $\begin{array}{r}-0.098 \\
* * *\end{array}$ & $\begin{array}{r}-0.073 \\
* * *\end{array}$ & $\begin{array}{r}-0.065 \\
* * *\end{array}$ & $\begin{array}{r}-0.107 \\
* * *\end{array}$ & 0.031 & 0.163 & 0.126 \\
\hline \& Education & $(0.018)$ & $(0.042)$ & $(0.026)$ & $(0.022)$ & $(0.025)$ & $(0.035)$ & & & \\
\hline \multirow[t]{2}{*}{ Science } & -0.036 & 0.036 & 0.012 & $\begin{array}{r}-0.039 \\
*\end{array}$ & $\begin{array}{r}-0.058 \\
*\end{array}$ & -0.054 & -0.090 & 0.046 & 0.026 \\
\hline & $(0.022)$ & $(0.047)$ & $(0.031)$ & $(0.024)$ & $(0.029)$ & $(0.042)$ & & & \\
\hline Engineering & 0.097 & 0.099 & 0.056 & 0.093 & 0.138 & 0.299 & 0.200 & -0.194 & 0.013 \\
\hline$\&$ & $* * *$ & $*$ & & $* * *$ & $* * *$ & $* * *$ & & & \\
\hline Architecture & $(0.031)$ & $(0.055)$ & $(0.045)$ & $(0.032)$ & $(0.039)$ & $(0.074)$ & & & \\
\hline Medicine \& & -0.048 & -0.044 & -0.042 & -0.043 & -0.026 & -0.005 & 0.039 & 0.068 & 0.103 \\
\hline Veterinary & $* * *$ & & & $*$ & & & & & \\
\hline Science & $(0.018)$ & $(0.040)$ & $(0.026)$ & $(0.021)$ & $(0.024)$ & $(0.038)$ & & & \\
\hline Social & -0.060 & -0.043 & -0.035 & -0.066 & -0.062 & -0.002 & 0.041 & 0.097 & 0.029 \\
\hline Science & $\begin{array}{r}* * * \\
(0023)\end{array}$ & $(0 \Omega 46)$ & (ח) & $\begin{array}{r}* * * \\
(0025)\end{array}$ & * & $(0046)$ & & & \\
\hline \multirow[t]{2}{*}{ Business } & -0.022 & 0.004 & -0.025 & -0.037 & -0.012 & 0.025 & 0.021 & 0.037 & 0.301 \\
\hline & (0.017) & (0.037) & $(0.024)$ & $\begin{array}{r}* \\
(0.019)\end{array}$ & $(0.023)$ & $(0.034)$ & & & \\
\hline \multirow[t]{2}{*}{ Law } & 0.025 & -0.028 & -0.063 & -0.026 & 0.053 & $\begin{array}{r}0.308 \\
*\end{array}$ & 0.336 & 0.010 & 0.008 \\
\hline & $(0.038)$ & $(0.052)$ & $(0.052)$ & $(0.037)$ & $(0.059)$ & $(0.132)$ & & & \\
\hline Mathematics & -0.039 & 0.008 & -0.021 & -0.048 & -0.047 & -0.071 & -0.079 & 0.068 & 0.118 \\
\hline \& Computer & & & & $*$ & * & $*$ & & & \\
\hline Science & $(0.018)$ & $(0.039)$ & $(0.026)$ & $(0.020)$ & $(0.024)$ & $(0.035)$ & & & \\
\hline
\end{tabular}




\begin{tabular}{l|rrrrrrrrr} 
Transport \& & -0.141 & -0.134 & -0.126 & -0.139 & -0.128 & -0.124 & 0.010 & 0.254 & 0.179 \\
Services & $* * *$ & $* * *$ & $* * *$ & $* * *$ & $* * *$ & $* * *$ & & & \\
& $(0.017)$ & $(0.037)$ & $(0.024)$ & $(0.019)$ & $(0.022)$ & $(0.032)$ & & & \\
Law & 0.079 & 0.096 & 0.077 & 0.069 & 0.096 & 0.088 & -0.008 & -0.173 & 0.061 \\
Enforcement & $* * *$ & $*$ & $* * *$ & $* * *$ & $* * *$ & $*$ & & & \\
& $(0.020)$ & $(0.042)$ & $(0.029)$ & $(0.023)$ & $(0.026)$ & $(0.037)$ & & & \\
\hline
\end{tabular}

Note: The coefficient values are statistically significant at all conventional levels of alpha $(* * * 0.01, * * 0.05$, and *0.10). Robust standard errors are shown in parenthesis. The dependent variable is the logarithmic of the real hourly wage rate.

Source: Own Calculations

Table 4: Summary of Wage Pattern of both Men and Women by Field of Study and Job Category.

\begin{tabular}{|c|c|c|c|c|}
\hline \multirow{3}{*}{$\begin{array}{l}\text { Job } \\
\text { Category }\end{array}$} & \multicolumn{4}{|c|}{ Wage Pattern: Private and Public Sector Workers } \\
\hline & \multicolumn{4}{|c|}{ Fields of Study } \\
\hline & Wage Increase & Wage Decrease & \multicolumn{2}{|c|}{ Highest Wage Gains } \\
\hline \multicolumn{5}{|c|}{ Panel A: Men } \\
\hline $\begin{array}{l}\text { Low } \\
\text { Income }\end{array}$ & $\begin{array}{l}\text { Medicine and Veterinary Science, } \\
\text { Transport and Services. }\end{array}$ & $\begin{array}{l}\text { Arts, humanities and education, science, } \\
\text { engineering and architecture, social } \\
\text { science, business, law, mathematics and } \\
\text { computer science, and law enforcement. }\end{array}$ & \multicolumn{2}{|c|}{$\begin{array}{l}\text { Medicine and } \\
\text { Veterinary Science, } \\
\text { Transport and } \\
\text { Services. }\end{array}$} \\
\hline $\begin{array}{l}\text { Middle } \\
\text { Income }\end{array}$ & Transport and services. & \multicolumn{2}{|c|}{$\begin{array}{l}\text { Arts, humanities and education, science, } \\
\text { engineering and architecture, medicine and } \\
\text { veterinary science, social science, business, law, } \\
\text { mathematics and computer science, and law } \\
\text { enforcement . }\end{array}$} & $\begin{array}{l}\text { Transport } \\
\text { and } \\
\text { services. }\end{array}$ \\
\hline $\begin{array}{l}\text { High } \\
\text { Income }\end{array}$ & $\begin{array}{l}\text { Science, engineering and architecture, } \\
\text { medicine and veterinary science, } \\
\text { social science, law, law enforcement. }\end{array}$ & $\begin{array}{l}\text { Arts, humanities and education, } \\
\text { business, mathematics and computer } \\
\text { science, transport and services. }\end{array}$ & \multicolumn{2}{|c|}{$\begin{array}{l}\text { Engineering and } \\
\text { architecture, } \\
\text { medicine and } \\
\text { veterinary science, } \\
\text { law enforcement. }\end{array}$} \\
\hline \multicolumn{5}{|c|}{ Panel B: Women } \\
\hline $\begin{array}{l}\text { Low } \\
\text { Income }\end{array}$ & $\begin{array}{l}\text { Arts, humanities and education, } \\
\text { science, engineering and architecture, } \\
\text { medicine and veterinary science, } \\
\text { social science, business, law, } \\
\text { mathematics and computer science, } \\
\text { transport and services, and law } \\
\text { enforcement }\end{array}$ & None & \multicolumn{2}{|c|}{$\begin{array}{l}\text { Science, } \\
\text { Engineering and } \\
\text { Architecture, and } \\
\text { Law. }\end{array}$} \\
\hline $\begin{array}{l}\text { Middle } \\
\text { Income }\end{array}$ & $\begin{array}{l}\text { Arts, humanities and education, } \\
\text { science, engineering and architecture, } \\
\text { medicine and veterinary science, } \\
\text { social science, business, mathematics } \\
\text { and computer science, and transport } \\
\text { and services. }\end{array}$ & Law, and law enforcement. & \multicolumn{2}{|c|}{$\begin{array}{l}\text { Science, engineering } \\
\text { and architecture. }\end{array}$} \\
\hline $\begin{array}{l}\text { High } \\
\text { Income }\end{array}$ & $\begin{array}{l}\text { Science, engineering and architecture, } \\
\text { medicine and veterinary science, } \\
\text { social science, business, law, transport } \\
\text { and services. }\end{array}$ & $\begin{array}{l}\text { Arts, humanities and education, } \\
\text { mathematics and computer science, law } \\
\text { enforcement. }\end{array}$ & \multicolumn{2}{|c|}{$\begin{array}{l}\text { Engineering and } \\
\text { architecture, social } \\
\text { science and law. }\end{array}$} \\
\hline
\end{tabular}

Source: Own Compilation based on Tables 2 and 3 above, of wage changes between 1991-2003, and 2004-2015. 